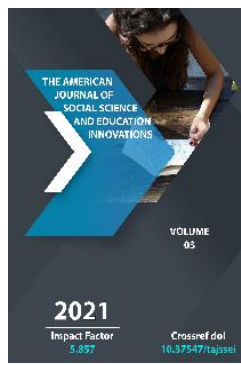

Journal Website: https://theamericanjou rnals.com/index.php/ta jssei

Copyright: Original content from this work may be used under the terms of the creative commons attributes 4.0 licence.

\section{Assessing The Quality Of Education Through The Eyes Of Students During A Pandemic}

\author{
Prof. Azizuddin Khan \\ IIT Bombay, India \\ Prof. K. Khasanova \\ Samarkand State University, Uzbekistan \\ Shakhzoda Bahtiyarovna Akhmedova \\ Doctoral Students, Samarkand, Uzbekistan
}

\title{
ABSTRACT
}

Conducted research in the form of a survey of students to improve the quality of education and improve the quality of optimization in the distribution of the required disciplines through the student's eyes.

\section{KEYWORDS}

Education, survey, students, optimization, recommendation, research, attention.

\section{INTRODUCTION}

Today, the world is experiencing the consequences of the COVID 19 pandemic, which has had side effects not only on global business, but also on the quality of education system. In the days of the pandemic, I had to adhere to strict quarantine and conduct studies at home, in which everyone had to understand a little that we were not yet ready to carry out this type of activity, outside the aisles of higher educational institutions. As such, teachers and students had to improve their skills in providing online learning.It can be noted that this research survey can attract our attention, each respondent who shared his opinion and views on improving education was very essential for us, we called this survey, which took place among students, as "Education through the young students' eye". 
The relevance of this research survey lies in the fact that it can contribute to the improvement of the educational process, which will allow SSU to reach a qualitative new level of development and comply with the internationally recognized quality standards in the field of education. This survey can serve as a basis for the development of management decisions to improve the educational process.

To study the issue of improving the educational process at SSU, a study was conducted to identify the opinions of students studying at the Faculty of Pedagogy regarding the educational process, which includes the curriculum, forms and methods of teaching and controlling, organization of practice and employment.
As a result of the research, students of the Faculty of Pedagogy were interviewed, the next courses II (20\%), III (55\%), IV (4\%), masters (21\%) and the following faculties: IEP (28\%), Russian Philology (7\%).

As a result of the survey, $80 \%$ confirmed the need to improve the educational process.

The survey revealed the main problems of students and the necessary improvements:

- $\quad$ Provide places of practice and assign to work after training;

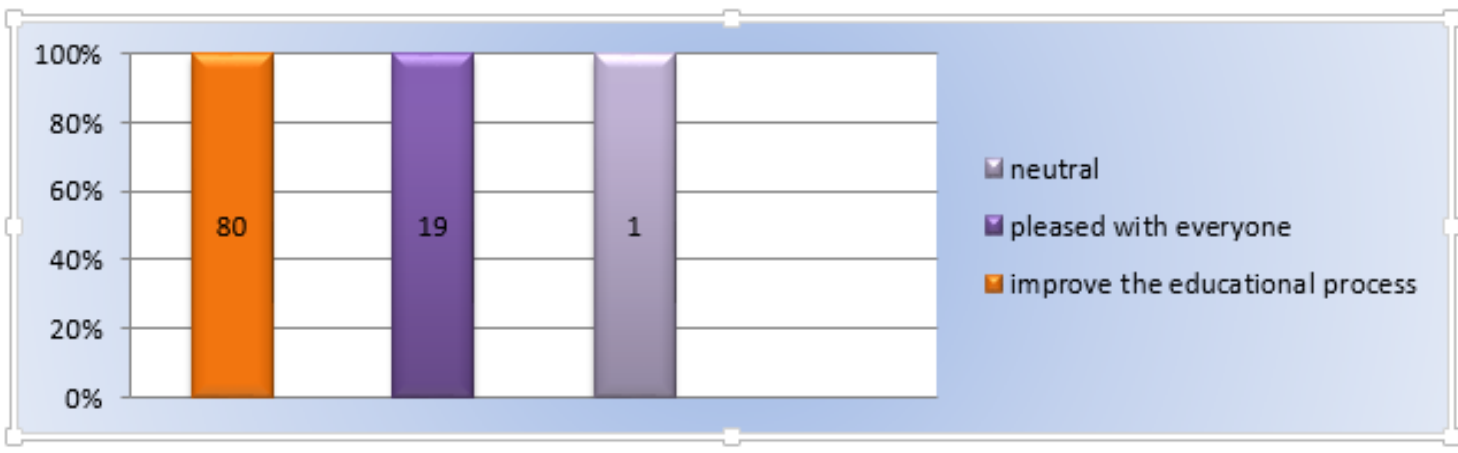

- $\quad$ Return specialty;

- Improve control methods;

- $\quad$ Computerize teaching methods;

- Use individual learning plans, with a choice of extracurricular activities and the elimination of couples that do not generate interest;

- $\quad$ Give priority to the time of classes in specialized subjects;

- Competently distribute the load of couples during the day (no windows) and during the week (approximately the same number of couples every day);

- $\quad$ Provide high quality and inexpensive power supply in the enclosures;

- Increase the loyalty of teachers in relation to students;

- Introduce business specialists into the educational process;

- $\quad$ Rejuvenate the teaching staff;

- Increase the interest of teachers in their work;

- $\quad$ Lower tuition fees; 
- $\quad$ Financially stimulate students: increase scholarships, pay bonuses for activity and scientific work;

- Improve the standard of living in hostels, create conditions with the Internet, introduce an electronic library in each of the buildings of the hostel;

- $\quad$ Update teaching materials to reflect modern changes;

- $\quad$ Strengthen the language training of students;

- Increase the number of consultations;

- Correct the scoring system for assessing knowledge;

- To systematize the work of the dean's office;

- $\quad$ To increase the factors motivating students in the learning process - to make the couple more interesting, to increase the variability of homework.

\section{CONCLUSION}

The study of the collected data allowed us to identify the benefits of the educational process, as well as formulate recommendations for improving the educational process:

- $\quad$ Fit hours into the curriculum set aside for group projects, in which students must explore a real problem or situation and find solutions using the knowledge gained during the study of the subject;

- Consideration should be given to leading a discussion between teacher and students during lectures, which helps to attract the attention of students and increases interest in the subject;

- $\quad$ Organize communication with native speakers in the framework of teaching a foreign language;

- $\quad$ Provide the opportunity to choose one or two subjects from other faculties of their own free will for selfdevelopment and self-determination [1];

- Develop a system of computer technology (create a web page for each subject, administered by the teacher, with the layout of all training materials and assignments;

- Provide the ability to upload completed assignments to the training server for verification by the teacher and quickly receive an assessment),

- $\quad$ To equip study places in each building for classes outside of lectures.

\section{REFERENSES}

1. Innovative Approach to the Organization of the Educational Process in Samarkand State University (On the Example of Students of the Pedagogical Faculty) // Test Engineering Management / / P.10284-10287.

2. https://www.surveymonkey.ru

3. "7 avlod vakillari sammiti" t.me/Yettiavlod_7G_Summit. 